\title{
The Legal Regime of Space Objects: Scientific Doctrine
}

\author{
Roman Shyshka \\ Doctor of Law, Professor, Kyiv Institute of Intellectual Property and Law \\ of the National University "Odessa Academy of Law" \\ (Kyiv, Ukraine) \\ E-mail: roman1353@ukr.net \\ https://orcid.org/0000-0002-0532-1909
}

The paper investigates the legal regime of space objects, namely: the order of their creation, introduction into legal circle and, in particular, the use and responsibility for the claimed rights to them. The author examines the acts of the current legislation, law-enforcement practices, formulates the scientific doctrine. The author suggests that in the legal regime for space objects having specific property rights as absolute. They provide the rights of owners who are dominant in the collision of real rights, in particular easements, and property rights, and are secured by imperative obligations for the return of artificial space objects to their owners.

Keywords: space objects, legal regime, property rights

\section{Правовий режим космічних об'сктів: наукова доктрина}

\section{Шишка, Роман Богданович}

Доктор юридичних наук, професор, професор кафедри інтелектуальної власності та цивільно-правових дисциплін Київського інституту інтелектуальної власності і права Національного університету «Одеська юридична академія»

(Київ, Україна)

В статті досліджусться правовий режим космічних об'єктів, а саме: порядок їх створення, введення в правовий обіг та, особливо, використання і відповідальності за заявлені права на них. Автор досліджує акти чинного законодавства, правозастосовні практики, формулює наукову доктрину. Автор припускає, щзо за правовим режимом на космічні об' 'єкти виникли особливі речові права, як абсолютні. Вони забезпечують права власників, які є домінуючими при колізії речових прав, зокрема сервітутів, та права власності, та забезпечені зобов'язаннями імперативного характеру щзодо повернення штучних космічних об'єктів їх власникам.

Ключові слова: космічні об'єкти, правовий режим, право власності

(C) Shyshka, Roman, 2018 
Received: June 23, 2018; accepted: August 3, 2018

Advanced Space Law, Volume 2, 2018: 63-69.

https://doi.org/10.29202/asl/2018/2/8

\section{Постановка проблеми}

Простір за межами земної атмосфери називають космічним простором. Він не зовсім порожній: у ньому є космічні об’єкти природного та штучного походження, на які заявлені права чи вони виникли внаслідок їх створення та запуску на орбіту, видаються сертифікати та свідоцтва тощо. Рано чи пізно до природних об'єктів виникає пізнавальний, а потім власницький інтерес: наразі не тільки на Місяць чи ділянки на ньому зареєстровані права, але навіть і на Сонце. Тож стосовно цих об'єктів виникають правовідносини, які є міжгалузевими, але наразі вони охоплюються предметом космічного права. Це призводить до непорозумінь, спорів і навіть конфліктів і потреби їм запобігати завдяки посиленню регулятивної та охоронної функцій права. Зокрема Індія провела експеримент зі збиття в космосі супутника внаслідок чого значно підвищилася суттєво небезпека для діючих комічних об'єктів штучного походження.

Здебільшого, дослідження і використання космічного простору, включаючи його об'єкти: Місяць та інші небесні тіла, а також штучні апарати, космічне сміття тощо здійснюється в країнах які:

а) Мають розвинуту космічну інфраструктуру. Це США, РФ, Великобританія, Франція, останні десятиріччя - досить посилено Китай та в останні роки Індія;

b) Проявляють чи мають свій інтерес у космічній сфері та є учасниками міжнародних та інших космічних програм. Наприклад, Україна;

c) Інші країни, незалежно від ступеня їх економічного чи наукового розвитку;

d) Приватні компанії, які створюють конкуренцію названим та інших державам.

Принаймні, космічний простір та небесні тіла відкриті для дослідження і використання всіма державами без будь-якої дискримінації на основі рівності й відповідно до міжнародного права при вільному доступі до всіх районів небесних тіл. Це створює загальні та локальні загрози для безпеки освоєння космосу.

Існує досить фундаментальна правова складова щодо врегулювання відносин стосовно космічних об'єктів. Їх основу становлять «Договір про принципи діяльності держав по дослідженню і використанню космічного простору, включаючи Місяць та інші небесні тіла», або скорочено «Договір про космос» [Договір, 1967], та «Угода про діяльність держав на Місяці та інших небесних тілах» [Угода, 1979]. Водночас не все, що визначене цими та іншими актами позитивного права, $є$ беззаперечне, навіть розумне 3 точки здійсненності співвідношення належного та сущого. Це стосується правового режиму об’ єктів як частини правового режиму космічного простору взагалі, чи як речей природного чи штучного походження зокрема. Насамперед йдеться про безпеку людства і недопущення його вимирання від наслідків вторгнення на Землю великих космічних об'єктів, а значить про відстеження орбіт космічних об'єктів та готовність їх змінити в разі загроз, упорядкування використання космічного простору космічними апаратами, прибирання його від космічного сміття, використання інформаційних ресурсів та 
мінімізації наслідків господарської, наукової та іншої, зокрема туристичної, діяльності в космосі.

Об’єктом дослідження є правовий режим космічних об’єктів як порядок їх створення, введення в правовий оборот та, особливо, використання і відповідальності за заявлені права на них. Предметом дослідження є акти чинного законодавства, правозастосовна практика, наукова доктрина.

\section{Виклад основного матеріалу}

Підхід розпадається на дві частини: встановлення семантичного та правового навантаження категорії «правовий режим об’єкта прав» і на цьому тлі визначення правового режиму космічних об'єктів природного та штучного походження. Щодо першого, то в юридичній літературі досі не склалось єдності і домінує формальне визначення правового режиму земельних ділянок, в основі якого є специфіка права власності на них чи порядок та спосіб введення у використання, можливості використання та припинення прав на такий об'єкт, яке екстраполюється щодо інших об'єктів прав або доктринальні підходи. Водночас з ним конкурує поняття «режим діяльності». В результаті їх пересікання виникають змішані конструкції.

Не вдаючись у їх аналіз, зауважимо, що йдеться про правову категорію та, у даному разі те, що стосовно цих об'єктів можуть виникнути чи існують права і охоронювані законом інтереси; вони мають певні фізичні властивості, які охоплюються цією категорією, зокрема можуть складати потенції небезпеки для інших космічних об’єктів, особливо штучного походження, міняти орбіти природних об'єктів та загрожувати негативними наслідками.

За порядком встановлення правовий режим космічних об'єктів може бути легальним (законним) чи договірним. Більше йдеться про другий, який $є$ прийнятним для міжнародного співтовариства.

Загальновизнано, що польоти космічних суден призначені для орбітального інерційного пересування в безповітряному просторі. На їх рух впливає сила тяжіння Землі та інших планет. Міжнародна авіаційна федерація (ФАI) реєструє політ судна як космічний, починаючи з висоти 100 км. На цій висоті космічний апарат може здійснити повний орбітальний оберт навколо Землі.

Міжнародно-правовий режим космічних об’єктів, як і космонавтів чи астронавтів, визначено рядом міжнародно-правових документів, як джерел міжнародного космічного права:

1. «Договір про принципи діяльності держав по дослідженню і використанню космічного простору, включаючи Місяць та інші небесні тіла» [Договір, 1967].

2. «Угода про рятування космонавтів, повернення космонавтів і повернення об’ єктів, запущених у космічний простір» [Угода, 1968].

3. «Конвенція про реєстрацію об’єктів, що запускаються в космічний простір» [Конвенція, 1975].

4. «Угода про діяльність держав на Місяці та інших небесних тілах» [Угода, 1979].

5. «Принципи використання державами штучних супутників Землі для міжнародного безпосереднього телевізійного мовлення» [Принципи, 1982].

Так згідно названого нами першого договору держава — його учасник, в реєстр якого внесені об'єкт, що запущений в космічний простір, зберігає юрисдикцію і контроль над 
ним та над екіпажом цього об'єкта протягом їх перебування в космічному просторі, в тому числі й на небесному тілі [Договір, 1967]. Принциповим є те, що право власності на космічні об'єкти, які запущені в космос, включаючи об’єкти, що доставлені чи споруджені на небесному тілі, та їх складові зберігають стан недоторканності під час їх перебування в космічному просторі чи на небесному тілі, чи по поверненні на Землю. Такі об'єкти чи їх складові частини, а також знайдені за межами держави-учасника Договору, в реєстр якого вони занесені, повинні бути повернені цій державі. При тому така держава повинна на вимогу надати до їх повернення розпізнавальні дані. У цій частині краще було б вказати ідентифікаційні дані.

При встановленні режиму космічного простору та небесних тіл, накопичилось певне непорозуміння, яке спричинене відсутністю загальновизнаного визначення цих територій та розуміння категорії «правовий режим». Як вважається, основною причиною такої невизначеності є відсутність у праві чіткого розрізнення між космосом і повітряним простором, який визнається територією держави. Досі космос нерідко визначають як простір, що знаходиться за межами повітряної сфери Землі, режим якого визначає міжнародне право ${ }^{1}$.

Виділяють простори, що мають особливості з погляду їхнього використання: ближній космос, дальній космос, геостаціонарну орбіту. Правовий режим цих просторів грунтується на існуючому режимі всього космічного простору. Проте, одне коли космічне тіло перебуває, рухається, міняє траєкторію руху у ближньому космічному просторі, а інше - у дальньому. Наприклад, коли супутники із атомними енергетичними установками сходять $з$ орбіт, то виникає проблема радіаційного зараження територій та відповідальності власників та шкоду довкіллю.

Основним міжнародно-правовим актом, що визначає режим дослідження та використання космічного простору та небесних тіл, $є$ «Договір про принципи діяльності держав по дослідженню і використанню космічного простору, включаючи Місяць та інші небесні тіла», або скорочено «Договір про космос» [Договір, 1967]. Договором встановлено, що дослідження та використання космічного простору, включно з Місяцем та іншими небесними тілами, здійснюється на благо та в інтересах всіх країн, незалежно від ступеня їхнього економічного або наукового розвитку, та $є$ надбанням всього людства. У його ст. 2 встановлено, що ніяка ділянка космічного простору, включно з небесними тілами, не підлягає національному привласненню ні шляхом проголошення на них суверенітету, ні шляхом використання або окупації, ні будь-якими іншими способами, а дослідження космічного простору слід проводити відповідно до міжнародного права, включно зі Статутом ООН [Договір, 1967].

Отже, космічні об'єкти природного походження не можуть бути об'єктами права власності. Проте є право першовідкривача та першоосвоювача, і рано чи пізно воно дасть про себе знати, особливо з реалізацією проекту місячних та марсіанських баз, хоча б за правом справедливості витрат на освоєння космічного простору. Чи не тому гонка в освоєнні ближнього та далекого космосу значно посилилася. Не виключені такі права і на штучні об'єкти, зокрема міжнародних космічних станцій. Якщо окремий їх модуль належить окремій державі чи приватній компанії, то в разі знищення чи пошкодження

${ }^{1}$ В Юридичному підкомітеті Комітету ООН з використання космічного простору у мирних цілях питання про делімітацію космосу обговорюється з 1967 р. і залишається поки невирішеним. Існуючі погляди на критерії делімітації іноді суттєво відрізняються, що не дозволяє говорити про наявність необхідного opinion juris. 
модулю персонал слід зберегти та надати можливість використати його ресурси для збереження життя.

Більше питань виникає стосовно штучних космічних об'єктів - штучних небесних тіл, засобів їх доставки, інших їх частин, які запущені чи споруджені в космічному просторі, чи на небесних тілах для їх дослідження, чи використання з мирною метою. Стосовно таких об'єктів зрозуміла структура правовідносин: визначено коло суб'єктів (країна, яка вивела в космос такий об’єкт) - учасник, що здійснив, організував запуск, надав установки чи територію, в тому числі й держава, яка здійснила ці дії як член міжнародної організації, яка займається космічною діяльністю на умовах, які передбачені Договором про космос особливе місце в цьому переліку відведене державі реєстрації космічного об'єкта, оскільки вона наділена юрисдикцією стосовно такого об'єкта.

Нагадаємо, що юрисдикція буває повна та обмежена. Повна юрисдикція означає владу держави наказувати поведінку і забезпечувати реалізацію своїх приписів всіма наявними в ii розпорядженні законними засобами. Обмежена юрисдикція означає, що держава може наказувати поведінку, однак вона в більшій чи меншій мірі обмежена у використанні засобів, що забезпечують виконання приписів.

Встановлення прав на штучні космічні об'єкти здійснюється за певними процедурами: держава за узгодженням із іншими учасниками вносить номер об'єкта у свій національний реєстр, повідомляє його та інші необхідні дані Генеральному секретарю ООН для внесення в Реєстр, який ведеться з 1961 р. Надалі за номером й іншими даними Реєстру ведеться ідентифікація об'єкта чи його частин в разі знаходження їх за межами території держави реєстрації чи на міжнародній території і повертається державі реєстрації. У всякому разі це перешкоджає поширенню на космічні об'єкти режиму знахідки. Юрисдикція держави реєстрації стосовно зареєстрованого об'єкта і його екіпажу зберігається на весь період перебування його в космосі, чи польоті. Тут йдеться про право власності на штучні космічні об'єкти, яке поширюється на космічний об'єкт, його частини, встановлену на ньому апаратуру, зразки, відкриття, цінності іншого характеру [Lyall \& Larsen, 2017].

Право власності на штучний космічний об'єкт може належати одній чи декільком державам, чи міжнародній організації, навіть приватній компанії. Щодо останнього, то в міжнародних документах пряма вказівка на приналежність космічних об'єктів приватним компаніям не передбачена і законодавець у цій частині запізнюється, що не бажане і повинне бути надолужене. Тим більше, що наразі розробляються і близькі до реалізації відповідні космічні програми, зокрема космічного туризму, виведені телекомунікаційні супутники приватних компаній, під них видаються розвідувальні системи. Це потребує чіткого визначення і закріплення прав публічних утворень на космічні штучні об'єкти 3 правами приватних осіб.

Держави вправі виводити космічні об'єкти на навколоземні та інші орбіти, здійснювати їх посадку на небесні тіла, запуск з них, розміщувати космічні апарати, обладнання, прилади, станції в любому місці поверхні небесних тіл чи в їх надрах, переміщати їх. Таке право набули й приватні компанії. Проте вони повинні інформувати Генерального секретаря ООН про місце розташування штучних космічних об’єктів, їх консервацію чи діяльність; випадки знаходження космічних об’єктів і негайно повертати їх державі реєстрації. Водночас, частини космічних штучних об'єктів чи самі об'єкти, які не мають розпізнавальних знаків і не зареєстровані належно, не повертаються. Тож йдеться лише про індивідуально визначені штучні космічні об'єкти як умову їх легітимації та захисту 
прав власників. На окремі космічні об'єкти природного походження, зокрема метеорити, держави здебільшого оголошують свої виключні права.

Серед космічних об'єктів виділяються аерокосмічні об'єкти чи «гібридні системи», які проходять через іноземні повітряні простори при приземленні, зміні орбіти, а також забезпечують транспортне сполучення пунктів на Землі та у космосі. Зустрічаються об’єкти невідомого походження (НЛО). Це пов'язане із забезпеченням національної та колективної безпеки цих країн та необхідністю їх інформувати про проходження такими об'єктами їх повітряного простору.

Держави-учасники Договору повинні негайно інформувати інші держави-учасники Договору чи Генерального секретаря ООН про встановлені ними явища в космічному просторі, включаючи Місяць та інші небесні тіла, які можуть бути небезпечними для життя чи здоров'я космонавтів. Видається, що тут слід було б доповнити вимогою про небезпеку довкіллю та космічному сполученню, особливо щодо штучних космічних об’єктів, над якими втрачено контроль.

Не менш важливим елементом правового режиму штучних космічних об'єктів є врегулювання витрат, які понесені на виявлення і повернення космічного об'єкта чи його складових. Вони згідно із договором покриваються державами чи організаціями, які здійснили їх запуск. Вважаємо, що такий підхід повинен бути збережений і щодо відшкодування завданого збитку від запуску та приземлення штучних космічних об'єктів.

Важливою є ст. 4 Договору про космос 1967 р. щодо заборони розміщення в космосі зброї масового знищення. Тим самим космічний простір і небесні тіла проголошені частково демілітаризованою зоною, включно з без'ядерним статусом [Договір, 1967]. Договором в космосі також заборонено проводити будь-які випробування ядерної зброї. Розміщення в космосі звичайних видів озброєння та збройних сил загальним міжнародним правом не заборонено, так само як не заборонено використання космосу для військових цілей. Деякі обмеження в цій галузі накладали лише двосторонні угоди. Водночас фахівці стверджують про мілітаризацію космосу.

Місяць та інші небесні тіла є демілітаризованими та нейтралізованими територіями, що забороняє будь-яке їх військове використання. Відповідно до Договору про космос вони можуть бути використані виключно в мирних цілях. Однак це не виключає права держави включати військовослужбовців у склад екіпажу космічного об'єкта (ст. 4) та їхнього права робити посадку на небесні тіла [Договір, 1967]. Так чи інакше спокуса використати ці об'єкти з військовою метою існує, і при нинішніх технологіях проконтролювати це і протистояти досить складно. Практика показує, що покладатися на чесне слово і завірення щодо чесності намірів та дотримання режиму космічного об'єкта не варто.

\section{Висновки}

Наразі з розвитком технологій та протистоянь заборонам та обмеженням як складової режиму космічних об'єктів приймаються обгрунтовані спроби розвинути й уточнити деякі положення Договору про космос [Договір, 1967] та Угоди про діяльність держав на Місяці та інших небесних тілах [Угода, 1979]. Зокрема, угода поширює на Місяць і небесні тіла режим «загального надбання людства» та приписує, щоб розробка природних ресурсів була тут підпорядкована спеціальному міжнародноправовому режиму. Однак ні Угода, ні інші міжнародно-правові акти такий режим не 
встановлюють. Це підтверджує, що міжнародне космічне право в частині визначення режиму небесних тіл значною мірою перебуває у сфері бажаного, ніж сущого, і багато дійсного залишається поза межами досяжності людства.

3 урахуванням наведеного, за правовим режимом космічних об'єктів можна припустити, що на них виникли особливі речові права, як абсолютні. Вони забезпечують права власників, які є домінуючими при колізії речових прав, зокрема сервітутів, та права власності та забезпечені зобов'язаннями імперативного характеру щодо повернення штучних космічних об’єктів їх власникам.

\section{Література}

Договір про принципи діяльності держав по дослідженню $і$ використанню космічного простору, включаючи Місяиь та інші небесні тіла. Прийняття від 27.01.1967. https://zakon.rada.gov.ua/laws/show/995_480

Конвениія про реєстрачію об'єктів, що запускаються в космічний простір. Прийняття від 14.01.1975. https://zakon.rada.gov.ua/laws/show/995_253

Принципи використання державами штучних супутників Землі для міжнародного безпосереднього телевізійного мовлення. Прийняття від 10.12.1982. https://zakon. rada.gov.ua/laws/show/995_497

Цивільний процесуальний кодекс України. Відомості Верховної Ради України (ВВР), 2004, № 40-41, 42, ст.492. https://zakon.rada.gov.ua/laws/show/1618-15

Угода про діяльність держав на Місяиі та інших небесних тілах. Прийняття від 18.12.1979. https://zakon.rada.gov.ua/laws/show/995_482

Угода про рятування космонавтів, повернення космонавтів і повернення об'єктів, запущених у космічний простір. Прийняття від 22.04.1968. https://zakon.rada.gov. ua/laws/show/995_483

Lyall, Francis, and Paul B. Larsen. Space Law: A Treatise. Routledge, 2017.

\section{References}

Dohovir pro pryntsypy diialnosti derzhav po doslidzhenniu i vykorystanniu kosmichnoho prostoru, vkliuchaiuchy Misiats ta inshi nebesni tila. Pryiniattia vid 27.01.1967. https:// zakon.rada.gov.ua/laws/show/995_480

Konventsiia pro reiestratsiiu obiektiv, shcho zapuskaiutsia v kosmichnyi prostir. Pryiniattia vid 14.01.1975. https://zakon.rada.gov.ua/laws/show/995_253

Pryntsypy vykorystannia derzhavamy shtuchnykh suputnykiv Zemli dlia mizhnarodnoho bezposerednoho televiziinoho movlennia. Pryiniattia vid 10.12.1982. https://zakon.rada. gov.ua/laws/show/995_497

Tsyvilnyi protsesualnyi kodeks Ukrainy. Vidomosti Verkhovnoi Rady Ukrainy (VVR), 2004, № 40-41, 42, st.492. https://zakon.rada.gov.ua/laws/show/1618-15

Uhoda pro diialnist derzhav na Misiatsi ta inshykh nebesnykh tilakh. Pryiniattia vid 18.12.1979. https://zakon.rada.gov.ua/laws/show/995_482

Uhoda pro riatuvannia kosmonavtiv, povernennia kosmonavtiv i povernennia obiektiv, zapushchenykh u kosmichnyi prostir. Pryiniattia vid 22.04.1968. https://zakon.rada.gov. ua/laws/show/995_483

Lyall, Francis, and Paul B. Larsen. Space Law: A Treatise. Routledge, 2017. 